\title{
PERAN MAHKAMAH KONSTITUSI SEBAGAI LEMBAGA PENGUJI UNDANG- UNDANG DALAM MASYARAKAT EKONOMI ASEAN
}

Oleh:

Januari Sihotang

\begin{abstract}
Constitutional Court is the guardian and single interpreter of the Constitution of 1945. Constitutional Court has authorities to review law against constitution including a law, which based on ratification of a treaty or convention. . Therefore, Constitutional Court has a role to implement and guard constitution of Indonesia in case the implementation of ASEAN Economic Community (AEC) as one main focus of ASEAN Charter could harm constitutional right of citizen and if the AEC is not in line with national goals of Indonesia according to constitution of 1945.
\end{abstract}

Keywords: Constitutional Court, international treaty, law / act.

\section{PENDAHULUAN}

Masyarakat ASEAN

(ASEAN Community 2015) merupakan wadah bagi negara-negara ASEAN untuk membangun kehidupan yang lebih baik bagi semua orang. Sesungguhnya, ASEAN Community baru akan terbentuk tahun 2020 tetapi berdasarkan hasil KTT ke-12 ASEAN, disepakati pembentukan Masyarakat ASEAN dari tahun 2020 dipercepat menjadi tahun 2015. ASEAN Community 2015 ini ditopang oleh tiga pilar utama, yaitu Masyarakat Politik dan Keamanan ASEAN, Masyarakat Ekonomi ASEAN, Masyarakat Sosial dan Budaya ASEAN. Salah satu yang menjadi fokus utama ASEAN Community adalah Masyarakat Ekonomi ASEAN 2015. Masyarakat Ekonomi ASEAN (selanjutnya disebut MEA) bertujuan untuk meningkatkan stabilitas perekonomian di kawasan ASEAN, dengan harapan
Masyarakat ASEAN mampu mengatasi masalah-masalah di bidang ekonomi.

Bagi Indonesia, pembentukan MEA ini sangat penting karena Indonesia memiliki berbagai potensi yang sangat menjanjikan di dalam pembangunan eknomi jika dikelola dengan baik seperti faktor sumber daya manusia, faktor sumber daya alam, faktor ilmu pengetahuan dan teknologi, faktor budaya dan faktor daya modal. Apalagi, salah satu kesepakatan MEA adalah adanya zona perdagangan bebas dan pasar tunggal ASEAN.

Namun, di sisi lain, keberadaan zona ekonomi bebas ASEAN juga menimbulkan beberapa kekhawatiran terkait kesiapan Indonesia. Kekhawatiran ini terkadang menimbulkan sebuah paradoks karena di satu sisi Indonesia mesti mendukung proses liberalisasi perdagangan barang dan jasa karena merupakan bukti ketundukan dan 
ketaatan pada perjanjian internasional, namun di sisi lain Indonesia juga perlu melakukan koreksi dan proteksi terhadap kepentingan nasional akibat efek negatif yang mungkin timbul.

Sebagai bentuk koreksi, Indonesia tentu harus melihat kembali kesiapan di bidang ekonomi terutama mengenai masalah kesiapan infrastruktur hingga kesiapan daya saing sumber daya manusia. Di bidang sosial dan politik, masyarakat Indonesia tentu harus siap untuk menghadapi persaingan bebas dan gaya hidup masyarakat luar negeri sehingga tidak mempengaruhi tatanan kehidupan masyarakat Indonesia yang sudah berjalan dengan baik selama ini.

Yang paling utama adalah koreksi sekaligus proteksi dalam bidang ideologi, konstitusi dan hukum. Tentu, arus liberalisasi akan membawa dampak dan pengaruh yang sangat signifikan. Oleh karena itu, unntuk mencegah agar arus liberalisasi tetap konstitusional maka Indonesia perlu mengkoreksi apakah peraturan maupun implementasi dari liberalisasi ekonomi ASEAN ini bertentangan atau tidak dengan UUD NRI Tahun 1945 dan Pancasila sebagai filter dan rambu. Bagaimanapun, Pancasila dan UUD NRI Tahun 1945 berfungsi mengawal liberalisasi perdagangan barang dan jasa agar tetap sesuai dengan tujuan pendirian bangsa Indonesia sebagaimana termaktub dalam UUD NRI Tahun 1945, yakni melindungi segenap bangsa dan seluruh tumpah darah Indonesia, memajukan kesejahteraan umum, mencerdaskan kehidupan bangsa dan ikut serta melaksanakan ketertiban dunia yang berdasarkan kemerdekaan, perdamaian abadi, dan keadilan sosial. Dengan demikian, apabila ternyata dalam pembentukan pasar bebas di kawasan ASEAN dihadapkan pada suatu pilihan antara kepentingan pasar bebas dengan kepentingan nasional, maka kepentingan nasional yang mesti didahulukan. ${ }^{1}$

Sebagai lembaga yang menjadi the guardian of constitution maupun sebagai the sole interpreter of constitution, Mahkamah Konstitusi memiliki peran yang sangat penting dalam menjaga agar setiap pelaksanaan liberalisasi perdagangan tersebut sesuai dengan Pancasila dan UUD NRI Tahun 1945. Bentuk perlindungan kepentingan nasional yang dilakukan oleh Mahkamah Konstitusi adalah melalui pengujian (judicial review) Undang-Undang yang dianggap telah melanggar atau merugikan hak konstitusional warga negara Indonesia.

\section{Tugas dan Kewenangan Mahkamah Konstitusi}

Konsep dasar pembentukan Mahkamah Konstitusi di berbagai negara sangat terkait dengan perkembangan prinsip-prinsip dan teori ketatanegaraan modern yang dianut oleh berbagai negara yang menganut prinsip konstitusionalisme, prinsip negara hukum, prinsip checks and balances, prinsip demokrasi dan jaminan perlindungan hak asasi manusia, prinsip peradilan yang bebas dan tidak memihak serta pengalaman politik dari masing-masing negara. Keberadaan Mahkamah Konstitusi dibutuhkan dalam menegakkan prinsip-prinsip tersebut.

\footnotetext{
1 Anwar Usman, Orasi Ilmiah Wakil Ketua Mahkamah Konstitusi dalam Rangka Dies Natalis Fakultas Hukum Universitas Kristen Maranatha, Bandung, 28 Agustus 2015
} 
Dengan kata lain, kehadiran Mahkamah Konstitusi adalah untuk melaksanakan prinsip konstitusionalisme dalam kehidupan bernegara. ${ }^{2}$ Pelanggaran terhadap konstitusi tentu tidak dapat ditolerir karena akan menimbulkan kekuasaan yang tiran dan semena-mena. Prinsip konstitusonalisme juga terkait dengan prinsip pemisahan dan pembatasan kekuasaan (checks and balances) $)^{3}$, yaitu kekuasaan lembagalembaga negara dibagi secara seimbang. Kekuasaan negara tidak boleh bertumpu pada satu lembaga negara karena akan dapat menimbulkan penyelahgunaan kekuasaan negara. ${ }^{4}$ Dalam mengawasi pelaksanaan kekuasaan lembaga-lembaga negara tersebut, agar tetap sesuai dengan kehendak rakyat diperlukan prinsip demokrasi dan penghormatan atas hak asasi mansuia. Artinya, karena kekuasaan negara bersumber dari rakyat maka akan selalu dapat dikontrol oleh rakyat dan selalu mengormati hak-hak dasar rakyat. Alat ukur bagi rakyat untuk mengawasi penyelenggaraan kekuasaan negara oleh lembaga negara adalah hukum dan

2 Konstitusionalisme merupakan paham yang berprinsip bahwa pelaksanaan kekuasaan negara oleh organ-organ negara harus berdasarkan ketentuanketentuan konstitusi. Lihat Jimly Asshiddiqie, Konstitusi \& Konstitusionalisme Indonesia, (Jakarta: Sekretariat Jenderal dan Kepaniteraan Mahkamah Konstitusi RI, 2006), hlm. 23-25.

${ }^{3}$ Lahirnya Konsep checks and balances tidak terlepas dari lahirnya pemikiran pentingnya pembatasan kekuasaan. Sebab jika kekuasaan tidak dibatasi, maka akan cenderung untuk disalahgunakan. Seperti dikatakan Montesquieu, bahwa: "experience shows us that every man invested with power is apt to abuse it, and to carry his uathority as far as it will go." Sebagaimana dikutip Hamdan Zoelva dalam Hamdan Zoelva, Pemakzulan Presiden di Indonesia, Jakarta: Sinar Grafika, 2011, hlm. 57-58.

4 Moh. Mahfud MD, Perdebatan Hukum Tata Negara Pascaamandemen Konstitusi, Jakarta: Rajawali Pers, 2013, hlm. 67-68. konstitusi. Disnilah prinsip negara hukum dan (rule of law) menjadi penting.

Kehadiran MK juga sangat urgen untuk menilai secara obyektif dan independen apakah suatu tindakan negara (lembagalembaga negara) yang tertuang dalam UU melanggar konstitusi atau tidak. MK akan mengawasi/mengimbangi dengan cara mengadili dan memutuskannya. Di sinilah konsep dasar dibutuhkannya Mahkamah Konstitusi yang berkembang sekarang ini. Untuk beberapa negara -khususnya yang menganut sistem hukum Anglo Saxonkewenangan judicial review dilaksanakan oleh MA, tetapi beberapa negara khususnya yang menganut sistem civil lawkewenangan judicial review dilaksanakan oleh MK yang berdiri sendiri di luar MA. ${ }^{5}$

Di Indonesia sendiri, proses pembentukan MK memiliki sejarah panjang yang penuh dengan perdebatan. Keinginan pembentukan sejenis MK untuk melakukan judicial review Undang-Undang terhadap Undang Undang Dasar sudah dimulai sejak Sidang BPUPKI 1945. Terjadi perdebatan

\footnotetext{
${ }^{5}$ Menurut Ni'matul Huda, di beberapa negara yang menganut sistem civil law, kewenangan judicial review hanya diberikan kepada satu lembaga tertinggi saja yang dikenal dengan Constitutional Court atau Mahkamah Konstitusi. Oleh karena tata cara pengujian hanya dilakukan oleh satu Mahkamah saja, maka sistem pengujian tersebut dikenal dengan nama sistem "sentralisasi", sedangkan metode pengujiannya disebut "principaliter". Sedangkan di beberapa negara lainnya yang menganut sistem common law, judicial review diberikan kepada para hakim yang bertugas untuk menguji apakah peraturan yang dipermasalahkan dalam kasus yang sedang diperiksa bertentangan atau tidak dengan konstitusi. Oleh karena prosedur pengujian tersebut dapat dilakukan oleh para hakim dalam pemeriksaan perkara secara konkrit, maka sistem ini disebut dengan sistem "desentralisasi" dan metode pengujiannya disebut "incidenter", Lihat Ni'matul Huda., 2008, "Urgensi Judicial Review dalam Tata Hukum Indonesia”, Jurnal Hukum, Volume 15, Nomor 1, Januari, 2008, hm. 104.
} 
yang cukup alot antara Soepomo dan Yamin waktu itu, namun pada akhirnya disimpulkan bahwa judicial review tidak diperlukan di Indonesia karena sistem yang dibangun adalah sistem permusyawaratan rakyat dalam bentuk MPR. Dengan demikian, secara langsung juga hal tersebut meniadakan lembaga judicial review sejenis MK di Indonesia. ${ }^{6}$

Gagasan pembentukan MK kembali bergulir dalam Sidang Umum MPR perihal perubahan UUD Tahun 2001. Pada Perubahan III UUD NRI Tahun 1945, Mahkamah Konstitusi diakomodasi dalam sistem ketatanegaraan Republik Indonesia melalui Pasal 24C UUD NRI Tahun 1945. Tercatat bahwa Indonesia merupakan negara ke 78 yang memiliki MK di seluruh dunia. Sebelumnya, dalam Pasal 24 ayat (2) UUD NRI Tahun 1945 juga sudah diatur bahwa kekuasaan kehakiman dilaksanakan oleh dua badan atau mahkamah yakni Mahkamah Agung dan Mahkamah Konstitusi. Kedua mahkamah ini memiliki kedudukan yang sederajat, tetapi memiliki fungsi dan peran yang berbeda.

Untuk memahami peran yang dilakukan oleh Mahkamah Konstitusi, haruslah dikaji dengan komprehensif kewenangankewenangan yang diberikan oleh UUD RI 1945 kepada lembaga ini. Pasal $24 \mathrm{C}$ ayat (1) menyebutkan bahwa Mahkamah Konstitusi berwenang untuk mengadili pada tingkat pertama dan terakhir dimana putusannya bersifat final. Dari ketentuan tersebut berarti Mahkamah Konstitusi bersifat tunggal yang tidak mempunyai peradilan yang berada di bawahnya dan tidak merupakan bawahan dari lembaga lain. Hal ini berbeda dengan Mahkamah Agung

\footnotetext{
${ }^{6}$ Ibid, hlm. 97-98.
}

yang mempunyai peradilan-peradilan di bawahnya dan merupakan puncak dari peradilan-peradilan yang berada dibawahnya. Dengan ketunggalannya dapat dikatakan bahwa Mahkamah Konstitusi adalam sebuah forum khusus untuk melakukan kewenangannya.

Di dalam menjalankan perannya sebagai penjaga konstitusi, maka Mahkamah Konstitusi Republik Indonesia diberi kewenangan seperti yang diatur dalam Pasal 24C ayat (1) UUD RI 1945 yang kemudian dipertegas dalam Undang-Undang Nomor 24 Tahun 2003 tentang Mahkamah Konstitusi yang menentukan bahwa Mahkamah Konstitusi berwenang mengadili:

a. Menguji undang-undang terhadap UUD NRI 1945;

b. Memutus sengketa kewenangan antar lembaga negara yang kewenangannya diberikan oleh UUD NRI 1945;

c. Memutus pembubaran partai politik;

d. Memutus perselisihan tentang hasil pemilu;

Selain putusan tugas dan kewenangan tersebut, Mahkamah Konstitusi juga memiliki kewajiban untuk memberi putusan atas pendapat Dewan Perwakilan Rakyat bahwa Presiden dan atau Wakil Presiden diduga telah melakukan pelanggaran hukum berupa penghianatan terhadap negara, korupsi, penyuapan, tindak pidana berat lainnya, atau perbuatan tercela, danatau tidak lagi memenuhi syarat sebagai Presiden dan atau Wakil Presiden, sebagaimana dimaksud dalam UUD RI 1945.

Berdasarkan beberapa kewenangan dan kewajiban MK tersebut dapat 
dikonstruksikan bahwa MK merupakan pengawal konstitusi yang berfungsi menegakkan keadilan konstitusional di tengah kehidupan masyarakat. Selain itu, Mahkamah Konstitusi juga bertugas untuk mendorong dan menjaga agar konstitusi dihormati dan dilaksanakan oleh semua komponen negara secara konsisten dan bertanggung jawab. Di tengah kelemahan sistem konstitusi yang ada, Mahkamah Konstitusi berperan sebagai penafsir agar semangat konstitusi selalu hidup dan mewarnai keberlangsungan bermasyarakat dan bernegara. ${ }^{7}$

\section{Kewenangan Mahkamah Konstitusi Menguji Undang-Undang Ratifikasi Perjanjian Internasional}

Berdasarkan Pasal 24C ayat (1) UUD NRI Tahun 1945, salah satu kewenangan Mahkamah Konstitusi adalah menguji (judicial review) Undang-Undang terhadap Undang-Undang Dasar yang putusannya bersifat final dan mengikat. Adapun materi muatan Undang-Undang yang menjadi objek kewenangan menguji MK adalah: a) pengaturan lebih lanjut mengenai ketentuan Undang-Undang Dasar Negara Republik Indonesia Tahun 1945; b) perintah suatu Undang-Undang untuk diatur dengan Undang-Undang; c) pengesahan perjanjian internasional tertentu; d) tindak lanjut atas putusan Mahkamah Konstitusi; dan/atau e) pemenuhan kebutuhan hukum dalam masyarakat. ${ }^{8}$

\footnotetext{
7 Maruarar Siahaan, Hukum Acara Mahkamah Konstitusi Republik Indonesia, Jakarta: Sinar Grafika, 2012, hlm. 7-8.

${ }^{8}$ Lihat Pasal 10 ayat (1) Undang-Undang Nomor 12 Tahun 2011 tentang Pembentukan Peraturan Perundang-Undangan.
}

Khusus Undang-Undang yang lahir dari pengesahan (ratifikasi) perjanjian internasional sesungguhnya dapat dikelompokkan menjadi dua bagian, yakni sebagai berikut: ${ }^{9}$

1. Undang-Undang yang lahir dari perjanjian internasional, namun masih membutuhkan implementation legislation dalam pelaksanaannnya. Undang-Undang ini misalnya Convention on the Law of The Sea yang diratifikasi dengan UndangUndang Nomor 17 Tahun 1985 tentang Pengesahan United Nations Convention on the Law of The Sea (Konvensi Perserikatan BangsaBangsa tentang Hukum Laut) yang ternyata masih membutuhkan Undang-Undang Nomor 6 Tahun 1996 tentang Perairan Indonesia.

2. Undang-Undang yang lahir dari perjanjian internasional, namun tidak memerlukan lagi implementation legislation sehingga dapat langsung dilaksanakan, misalnya Vienna Convention on Diplomatic Relation 1961 dan Vienna Convention on Consular Relation 1963 yang diratifikasi menjadi Undang-Undang Nomor 1 Tahun 1982 tentang Pengesahan Konvensi Wina Mengenai Hubungan Diplomatik.

Dengan demikian, dapat disimpulkan bahwa Undang-Undang yang memuat tentang ratifikasi dibagi atas dua, yakni Undang-Undang Ratifikasi itu sendiri dan

\footnotetext{
9 Andi Sandi Ant. T T dan Agustina Merdekawati, "Konsekuensi Pembatalan Undang-Undang Ratifikasi Terhadap Keterikatan Pemerintah Indonesia pada Perjanjian Internasional", Jurnal Mimbar Hukum UGM, Volume 24, Nomor 3, oktober 2012, hlm. 460.
} 
Undang-Undang Implementasi. MEA sendiri merupakan salah satu kesepakatan yang lahir dari Piagam ASEAN (ASEAN Charter) yang kemudian diratifikasi dengan Undang-Undang Nomor 38 Tahun 2008. Berdasarkan pembagian di atas, UndangUndang Nomor 38 Tahun 2008 ini merupakan Undang-Undang Ratifikasi yakni Undang-Undang yang hanya merupakan pengesahan perjanjian internasional sebagai bentuk persetujuan DPR sebagaimana diatur dalam Pasal 11 UUD NRI Tahun 1945.

Sebelumnya timbul perdebatan mengenai dapat tidaknya sebuah UndangUndang yang merupakan ratifikasi perjanjian internasional diuji oleh MK. Beberapa pihak yang tidak setuju dengan kewenangan tersebut pada umumnya berpendapat bahwa Undang-Undang Ratifikasi bukan wet in formele zijn sehingga bukan merupakan UU yang dapat dimohonkan pengujiannya di MK. Karena keberadaan Undang-Undang ratifikasi mengacu kepada Pasal 11 UUD NRI Tahun 1945, bukan Pasal 5, Pasal 20 dan Pasal 22A UUD 1945. Dengan kata lain, proses penyusunan Undang-Undang tersebut tidak melibatkan peran Presiden dan DPR mulai dari perencanaan, penyusunan, pembahasan, persetujuan, pengesahan dan pengundangan sebagaimana layaknya pembentukan sebuah Undang-Undang. ${ }^{10}$ Apalagi, isi sebuah Undang-Undang Ratifikasi adalah hanya pengesahan perjanjian internasional, sedangkan materi muatan perjanjian internasional tersebut ditempatkan pada bagian Lampiran dari Undang-Undang tersebut.

${ }^{10}$ Lihat Pasal 1 Undang-Undang Nomor 12 Tahun 2011 tentang Pembentukan Peraturan PerundangUndangan.
Namun, akhirnya perdebatan tersebut dapat dijawab oleh Mahkamah Konstitusi dalam Putusan Nomor 33/PUU-IX/2011 tentang Pengujian Undang-Undang Nomor 38 Tahun 2008 tentang Pengesahan Charter of the Association of Southeast Asian Nations (Piagam Perhimpunan BangsaBangsa Asia Tenggara)

terhadap Undang-Undang Dasar Negara Republik Indonesia Tahun 1945. MK menyatakan berwenang untuk menguji Undang-Undang hasil ratifikasi dengan pertimbangan sebagai berikut:

1. Perjanjian internasional yang dibuat oleh Negara Indonesia didasarkan atas adanya kedaulatan yang dimiliki oleh Negara Indonesia;

2. Negara Indonesia mempunyai kebebasan penuh untuk mengikatkan diri atau tidak mengikatkan diri dengan negara lain dalam sebuah perjanjian internasional, masuk atau tidak masuk, ikut atau tidak ikut serta pada perjanjian internasional yang telah ada;

3. Meskipun Negara Indonesia telah mengikatkan diri dalam suatu perjanjian internasional, namun sebagai sebuah negara yang berdaulat Negara Indonesia tetap mempunyai hak secara mandiri untuk memutus keterikatan dengan perjanjian internasional yang telah dibuat atau yang padanya negara Indonesia terikat, setelah secara internal mempertimbangkan keuntungan atau kerugiannya baik untuk tetap terikat, ataupun untuk tidak terikat dengan mempertimbangkan risiko atas 
keputusan untuk keluar dari suatu perjanjian internasional.

\section{Implikasi Pengujian Undang-Undang Hasil Ratifikasi Perjanjian Internasional}

Oleh karena Mahkamah Konstitusi menyimpulkan berwenang untuk menguji Undang-Undang hasil ratifikasi perjanjian internasional, maka yang perlu diperhatikan selanjutnya adalah implikasi hukum dari Putusan MK terhadap keberadaan UndangUndang hasil ratifikasi perjanjian internasional tersebut. Secara umum, ada tiga jenis Putusan MK, yakni 1) Permohonan tidak diterima; 2) Permohonan ditolak; 3) Permohonan dikabulkan. Jika permohonan tidak diterima dan ditolak, maka putusan tersebut sesungguhnya tidak memiliki implikasi hukum yang terlalu signifikan terhadap eksistensi UndangUndang Ratifikasi dan Perjanjian Internasional tersebut. Undang-Undang hasil ratifikasi akan tetap eksis sebagaimana sebelum adanya permohonan ke Mahkamah Konstitusi. Implikasi hukum baru ada ketika permohonan dikabulkan oleh Mahkamah Konstitusi. Artinya, ketika permohonan dikabulkan, maka Undang-Undang yang mengatur tentang Ratifikasi Perjanjian Internasional tersebut akan batal.

Pertanyaannya, apakah ketika UndangUndang hasil ratifikasi dibatalkan oleh Mahkamah Konstitusi maka akan membatalkan keterlibatan dan kepatuhan Indonesia dalam perjanjian internasional yang telah disetujui sebelumnya? Jika Undang-Undang yang dibatalkan adalah Undang-Undang Implementasi Perjanjian Internasional, maka Putusan MK bisa saja membatalkan sebagian atau seluruhnya isi/materi daripada Undang-Undang.
Artinya, jika Undang-Undang Implementasi tersebut dibatalkan sebagian, maka bukan berarti menghapus keberadaan UndangUndang Implementasi Perjanjian Internasional tersebut. Hanya saja, muncul kewajiban bagi DPR dan Presiden untuk membuat Undang-Undang yang baru untuk mengatur mengenai hasil perubahan sesuai dengan Putusan MK. .

Namun, masalahnya akan berbeda jika yang dibatalkan adalah Undang-Undang pengesahannya sendiri yang tentu akan membatalkan keseluruhan isi dan keterikatan Indonesia pada perjanjian internasional tersebut. Pembatalan UndangUndang Pengesahan Perjanjian Internasional akan mempengaruhi posisi Indonesia apalagi jika dikaitkan dengan asas perjanjian internasional pacta sunt servanda. Harus dipahami, bahwa Indonesia tidak bisa begitu saja menarik diri dari perjanjian internasional ketika Putusan Mahkamah Konstitusi membatalkan Undang-Undang. Hal tersebut tidak bisa dilakukan karena untuk melakukan penarikan diri dari suatu perjanjian internasional juga harus sesuai dengan ketentuan-ketentuan yang telah disepakati dalam beberapa perjanjian internasional.

Menurut Pasal 54a Konvensi Wina 1969, jika suatu negara dianggap mengundurkan/menarik diri dari suatu perjanjian internasional, maka penarikan diri harus dilakukan sesuai dengan ketentuan yang terdapat di dalam perjanjian internasional tersebut. Jika perjanjian internasional tersebut tidak mengatur mengenai mekanisme pengunduran diri, maka penarikan diri harus membutuhkan persetujuan negara pihak pembuatan 
perjanjian internasional yang lainnya. ${ }^{11}$ Kendati banyak hal yang harus dipertimbangkan ketika harus melakukan penarikan diri dari suatu perjanjian internasional karena bagaimanapun, jika misalnya amar putusan Mahkamah Konstitusi menyatakan mengabulkan permohonan maka kepercayaan masyarakat internasional atas Indonesia dapat berkurang karena Indonesia dianggap tidak bersungguh-sungguh ikut serta dan melaksanakan perjanjian dengan baik dengan alasan bertentangan dengan hukum nasional. $^{12}$ Negara Indonesia juga bisa dianggap tidak memiliki grand design yang jelas dan komprehensif mengenai konsep pembangunan bangsa dan negara, khususnya yang menyangkut pembangunan yang berhubungan dengan dunia internasional.

Sama dengan perjanjian internasional lainnya, hal yang sama juga terjadi dalam konteks MEA, peran judicial review yang dilakukan oleh Mahkamah Konstitusi bersifat pasif. Artinya, MK baru dapat melaksanakan fungsinya jika ada permohonan warga negara yang merasa hak konstitusionalnya dilanggar (tidak terlindungi) dengan keberadaan MEA tersebut. Selain itu, warga negara juga bisa melakukan permohonan judicial review kepada setiap Undang-Undang yang dibuat terkait dengan upaya untuk mendukung MEA tersebut.

Jika seandainya Mahkamah Konstitusi membatalkan Undang-Undang Ratifikasi Piagam ASEAN (Undang-Undang Nomor

\footnotetext{
${ }^{11}$ Pasal 56 Konvensi Wina 1969.

$12 \mathrm{Ni}$ Ketut Aprilyawathi, "Wewenang Mahkamah Konstitusi dalam Pengujian Undang-Undang Hasil Ratifikasi Perjanjian Internasional yang Bersifat Multilateral", Jurnal Yuridica, Volume 30 Nomor 1, Januari-April 2015, hlm. 10.
}

38 Tahun 2008 tentang Pengesahan Charter of the Association of Southeast Asian Nations (Piagam Perhimpunan BangsaBangsa Asia Tenggara), maka Indonesia harus meminta izin penarikan diri kepada negara-negara penandatangan Piagam ASEAN yang lain. Jika misalnya para negara-negara peserta tidak memberikan izin penarikan diri, maka prosesnya dilanjutkan ke Konferensi Tingkat Tinggi (KTT) ASEAN. ${ }^{13}$

Untuk menghindari terjadinya hal seperti ini, maka alangkah baiknya jika seandainya jika pemerintah bersama-sama dengan DPR lebih berhati-hati ketika akan ikut dan menandatangani sebuah perjanjian internasional, terutama jika perjanjian internasional tersebut berdampak luas terhadap kehidupan berbangsa dan bernegara. Sebab jika tidak hati-hati, penarikan diri dari sebuah perjanjian internasional bisa saja terjadi yang tidak saja merugikan warga negara dan negara, tetapi juga mempengaruhi eksistensi negara di mata dunia internasional.

\section{KESIMPULAN}

Adapun kesimpulan dalam tulisan ini adalah bahwa Mahkamah Konstitusi memiliki peran yang sangat urgen dalam MEA. Sebagai lembaga yang berfungsi untuk mengawal dan menafsirkan konstitusi, maka Mahkamah Konstitusi dapat menguji Undang-Undang tentang Pengesahan Piagam ASEAn maupun Undang-Undang impelementasinya yang dianggap bertentangan dengan UUD NRI Tahun 1945. Hal ini sangat penting demi melindungi kepentingan nasional dan kedaulatan

\footnotetext{
${ }^{13}$ Lihat Pasal 20 Piagam ASEAN
} 
bangsa, serta hak konstitusional warga negara.

Adapun saran-saran penulis adalah bahwa demi terjaganya nilai-nilai Pancasila dan UUD NRI Tahun 1945 dalam kehidupan berbangsa dan bernegara, khususnya dalam pergaulan internasional yang berujung dengan terciptanya beberapa perjanjian internasional, maka dibutuhkan beberapa perubahan dalam desain ketatanegaraan Indonesia khususnya mengenai pengesahan perjanjian internasional. Jika sebelumnya bentuk persetujuan DPR terhadap suatu perjanjian internasional adalah ketika pengesahan /ratifikasi perjanjian internasional menjadi Undang-Undang, maka ada baiknya jika sebelum disahkan oleh DPR terlebih dahulu diminta pendapat MK (judicial preview) terkait perjanjian internasional tersebut bertentangan atau tidak dengan UUD NRI Tahun 1945. Hal ini sangat penting untuk memastikan bahwa Indonesia sangat konsisten dengan kebijakan pembangunan, termasuk hubungan luar negeri yang harus mengutamakan kemaslahatan dan kemakmuran bangsa sesuai dengan amanat UUD NRI Tahun 1945.

\section{Daftar Pustaka}

\section{Buku dan Jurnal Ilmiah}

Anwar Usman, Orasi Ilmiah Wakil Ketua Mahkamah Konstitusi dalam Rangka Dies Natalis Fakultas Hukum Universitas Kristen Maranatha, Bandung, 28 Agustus 2015

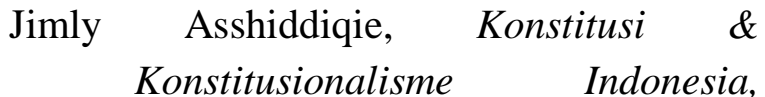

Sekretariat Jenderal dan Kepaniteraan Mahkamah Konstitusi RI, Jakarta, 2006

Hamdan Zoelva, Pemakzulan Presiden di Indonesia, Jakarta: Sinar Grafika, 2011

Moh. Mahfud MD, Perdebatan Hukum Tata Negara Pascaamandemen Konstitusi, Jakarta: Rajawali Pers, 2013.

Maruarar Siahaan, Hukum Acara Mahkamah Konstitusi Republik Indonesia, Jakarta: Sinar Grafika, 2012.

Andi Sandi Ant. $\mathrm{T}$ T dan Agustina Merdekawati, "Konsekuensi Pembatalan Undang-Undang Ratifikasi Terhadap Keterikatan Pemerintah Indonesia pada Perjanjian Internasional", Jurnal Mimbar Hukum UGM, Volume 24, Nomor 3, oktober 2012.

$\mathrm{Ni}$ Ketut Aprilyawathi, "Wewenang Mahkamah Konstitusi dalam Pengujian Undang-Undang Hasil Ratifikasi Perjanjian Internasional yang Bersifat Multilateral", Jurnal Yuridica, Volume 30 Nomor 1, Januari-April 2015.

Ni'matul Huda, "Urgensi Judicial Review dalam Tata Hukum Indonesia", Jurnal Hukum, Volume 15, Nomor 1, Januari, 2008. 


\section{Peraturan Perundang-Undangan}

Undang-Undang Dasar Negara Republik Indonesia Tahun 1945

Undang-Undang Nomor 12 Tahun 2011 tentang Pembentukan Peraturan Perundang-Undangan.

Undang-Undang Nomor 24 Tahun 2003 tentang Mahkamah Konstitusi

Putusan Mahkamah Konstitusi Nomor 33/PUU-IX/2011 tentang Pengujian Undang-Undang Nomor 38 Tahun 2008 tentang hasil ratifikasi Piagam ASEAN 